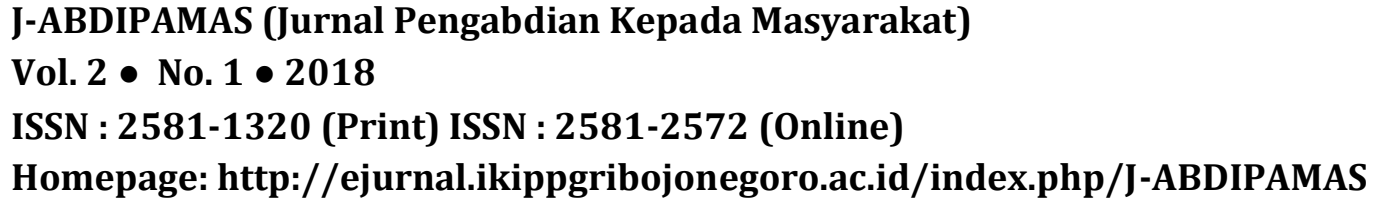

\title{
APLIKASI TEKNOLOGI SEDERHANA DAN PERMESINAN UNTUK MENINGKATKAN KEAHLIAN RENOVASI LAMBUNG PERAHU
}

\author{
Seno Darmanto ${ }^{1}$, Sutanto $^{2}$, Sulaiman ${ }^{3}$, Eko Julianto Sasono ${ }^{3}$ \\ ${ }^{1}$ Universitas Diponegoro. Email: senodarmanto@gmail.com \\ 2Universitas Diponegoro. Email: sutantocivil@gmail.com \\ 3Universitas Diponegoro. Email: sulaimannaval@gmail.com \\ ${ }^{4}$ Universitas Diponegoro. Email: ekojuliantosasono@gmail.com
}

\begin{abstract}
Applications of technology and machinery equipment in service activities are done to complete the renovation and repair of boats or wooden vessels. Development of the infrastructure for members of the fishermen group is currently focused on equipment for the repair and renovation of the boat hull and the maintenance of the driving machine. And for the improvement of the renovation or repair of the boat hull, the service team has compiled a working activity including understanding and deepening of boat or wooden boats, engineering and equipment for renovation and boatbuilding, understanding and deepening of ship damage, and implementation in a group of fishermen. The process of maintenance and repair of boats on the ship's body (hull) in fishermen partners in principle were carried out through several stages include the washing and cleaning of all parts of the ship, patching, coating and painting. The process of painting through several stages of surface cleaning, patching if there are starting cracks and holes, drying, smoothing, basic coating and painting. Some tools for boats maintenance and repair especially for renovation and manufacture of wooden boats consist of saws (machines and manuals), drills, fittings, grinders, cutting (various sizes), clamps and other support equipment
\end{abstract}

Keywords: boat, hull, propulsion machine, machinery

\begin{abstract}
ABSTRAK
Kegiatan pengabdian aplikasi teknologi dan peralatan permesinan dilakukan untuk menyempurnakan renovasi dan perbaikan perahu atau kapal kayu. Pengembangan kelengkapan sarana anggota kelompok nelayan pada saat ini difokuskan pada peralatan untuk perbaikan dan renovasi lambung atau bodi dan perawatan mesin penggerak. Dan untuk penyempurnaan renovasi atau perbaikan kapal kayu, tim pengabdian menyusun langkah kerja atau kegiatan pengabdian meliputi pemahaman dan pendalaman perahu atau kapal kayu, teknik dan peralatan renovasi dan pembuatan perahu, pemahaman dan pendalaman kerusakan kapal, dan sejenisnya dan pelaksanaan di kelompok nelayan. Proses perawatan dan perbaikan kapal pada bagian badan kapal (lambung kapal) di mitra nelayan pada prinsipnya dilakukan melalui beberapa tahapan meliputi pencucian seluruh bagian kapal, penambalan (pemakalan), pendempulan dan pengecetan kapal. Proses pengecatan melalui beberapa tahapan yakni pembersihan permukaan, penambalan kalau ada yang mulai retak dan berlubang, pengeringan, penghalusan, pelapisan dasar dan pengecatan. Beberapa peralatan perawatan dan perbaikan lambung perahu terutama untuk renovasi dan pembuatan perahu kayu meliputi gergaji kayu (mesin dan manual), bor, pasah, gerinda, tatah (berbagai ukuran), clem/pencepit dan peralatan pendukung lain
\end{abstract}

Kata Kunci: perahu sopek, lambung, mesin penggerak, permesinan 


\section{PENDAHULUAN}

Kelompok nelayan Wahana Bahari merupakan kelompok nelayan besar yang terletak di daerah perbatasan antara Kabupaten Semarang dan Demak dan tepatnya di dukuh Surodadi kelurahan Gandong kecamatan Sayung Kabupaten Demak Jawa Tengah. Kelompok ini sudah berdiri lebih dari 30 tahun yang lalu dan menjadi cikal bakal kelompok-kelompok nelayan saat ini di mana anggota kelompok telah mencapai lebih dari 200 orang. Untuk memudahkan koordinasi pengurus dengan seluruh anggota, kelompok nelayan Wahana Bahari berusaha untuk memekarkan menjadi kelompok kecil (cluster) binaan dengan anggota rata-rata 10 - 25 orang dan salah satu kelompok bianaan Rejeki Bahari. Kelompok nelayan Rejeki Bahari dipimpin ketua dan dibantu oleh sekretaris dan bendahara. Untuk urusan umum di kelompok seperti keamanan, tempat tambat perahu, jaring dan lelang ikan dikelola bersama dengan dikoordinasi pengurus. Jaga malam dilakukan secara kelompok. Sedangkan untuk kebutuhan pakan tambak, perlakuan ikan dan perlakuan limbah ikan diserahkan masing-masing anggota. Urusan pribadi anggota yang menghasilkan profit diminta memberikan iuran (fee) ke kelompok meliputi penjualan ikan dan rajungan, penjualan pakan ikan, penambahan ikan dan penitipan ikan. Rapat pengurus dengan anggota dilaksanakan (diharapkan) tiap bulan secara rutin.

Potensi besar di sektor perikanan perlu penanganan yang arif, berkelanjutan, ramah lingkungan dan disertai dengan kebijakan dari pemerintah secara cermat dan tegas. Sumberdaya perikanan merupakan kekayaan alam milik bersama (common property) dan siapapun boleh memanfaatkannya (open access) (Yahya, 2001). Paradigma ini secara umum dipahami dengan pengelolaan sumberdaya perikanan tidak terbatas, sehingga mengakibatkan beberapa wilayah perairan kita mengalami kelebihan penangkapan (over fishing). Di sisi lain, keterbatasan sumberdaya perikanan membuat nelayan semakin sulit untuk mendapatkan hasil tangkapan. Kondisi ini kemudian disikapi dengan meningkatkan kecepatan kapal atau daya atau jumlah mesin kapal. Penambahan daya dan jumlah mesin kapal tanpa disadari dapat menyebabkan biaya operasi (operation cost) semakin membengkak sedangkan hasil tangkapan (sumberdaya) ikan semakin terbatas. Kondisi ini menyebabkan persaingan yang semakin ketat dan menimbulkan konflik antar nelayan. Apa lagi bila terjadi kenaikkan harga bahan bakar minyak, hal ini dapat membawa dampak yang luas pada usaha perikanan tangkap. Kenaikkan harga bahan bakar solar menyebabkan biaya operasi penangkapan (operation cost of capture) semakin tinggi sedangkan di sisi lain sumberdaya ikan (fish resources) semakin terbatas. Kondisi ini berakibat pada meningkatnya tingkat persaingan usaha perikanan tangkap dan konflik nelayan. Berdasarkan kajian menunjukkan bahwa keterbatasan sumberdaya perikanan merupakan penyebab utama dari konflik nelayan di perairan Pekalongan. Keterbatasan sumberdaya perikanan disebabkan oleh pola tangkap nelayan yang tidak memperhatikan kelestarian sumberdaya perikanan dan lingkungan (Muhammad, 2002). 
Meskipun potensi bahari indonesia sangat besar, permasalahan di lingkungan nelayan juga komplek. Berdasarkan kajian lapangan dan literatur menunjukkan bahwa problem utama di lingkungan nelayan adalah kemiskinan, lingkungan kumuh, sanitasi, kesehatan, pendidikan kriminalitas dan sektor pendukung nelayan (Rois, 2016, Subhari, 2016). Kemiskinan menjadi masalah utama nelayan tradisional yang mendasarkan penghasilannya hanya pada tangkapan produk laut. Penghasilan menjadi lebih merosot jika nelayan menjual tangkapan ikan langsung ke tengkulak. Instansi pemerintah dan lembaga swadaya masyarakat secara rutin dan bertahap telah memperbaiki problem lingkungan, sanitasi, kesehatan, pendidikan kriminalitas, meskipun saat sekarang masih perlu perbaikan dan pembenahan lagi secar berkelanjutan. Sektor pendukung nelayan yang meliputi tempat lelang ikan, koperasi/paguyuban, bengkel (galanagan) dan pengolahan tangkapan ikan perlu dihadirkan untuk membekali nelayan dalam menangkap dan memasarkan ikan serta perbaikan perahu.

Permasalahan di galangan perahu dan kapal kecil berdampak pada perawatan, perbaikan dan pembangunan perahu atau kapal baru. Perawatan dan perbaikan perahu pada dasarnya terdiri dari 4 (empat) bagian meliputi alat tangkap, mesin penggerak, alat bantu dan bodi/lambung perahu. Di waktu luang atau tidak melaut, nelayan biasanya memperbaiki alat tangkap (jaring, jebakan, alat bantu) yang rusak. Selanjutnya berdasarkan identifikasi di lapangan, perawatan perahu atau kapal kecil di kelompok nelayan sebagian besar dilakukan oleh pihak ketiga/jasa konstruksi kapal sehubungan dengan keterbatasan sumberdaya dan peralatan perawatan. Perawatan pelapisan lambung perahu perlu dilakukan setiap tahun. Kemudian perawatan mesin penggerak (mesin diesel) biasanya kurang maksimal meskipun nelayan mempunyai panduan perawatan mesin secara lengkap. Keterbatasan perawatan dan perbaikan perahu berdampak langsung dengan keamanan/keselamatan nelayan selama melaut.

Berdasarkan kajian lapangan dan literatur menunjukkan bahwa problem utama di lingkungan nelayan adalah kemiskinan, lingkungan kumuh, sanitasi, kesehatan, pendidikan kriminalitas dan sektor pendukung utama pekerjaan nelayan (Rois, 2016, Subhari, 2016). Kemiskinan menjadi masalah utama nelayan tradisional yang mendasarkan penghasilannya hanya pada tangkapan produk laut. Selanjutnya sektor pendukung nelayan yang meliputi tempat lelang ikan, koperasi/paguyuban, bengkel perawatan perahu (galangan) dan pengolahan tangkapan ikan juga menjadi kendala dan kesulitan yang perlu diselesaikan secara bersama, bertahap dan berkelanjutan. Permasalahan di galangan perahu dan kapal kecil berdampak pada perawatan, perbaikan dan pembangunan perahu atau kapal baru. Perawatan dan perbaikan perahu pada dasarnya terdiri dari 4 (empat) bagian meliputi alat tangkap, mesin penggerak, alat bantu dan bodi/lambung perahu. Selanjutnya berdasarkan identifikasi di lapangan, perawatan perahu atau kapal kecil di kelompok nelayan sebagian besar dilakukan oleh pihak ketiga/jasa konstruksi kapal sehubungan dengan keterbatasan sumberdaya dan komponen/peralatan perawatan. Dan berdasarkan kesepakatan dengan pengelola kelompok nelayan Rejeki Bahari, 
kegiatan pengabdian ke depan difokuskan pada perawatan, perbaikan dan teknik pembuatan perahu sopek atau kapal kecil teristimewa pada mesin penggerak dan lambung perahu. Dan solusi yang akan diberikan selama kegiatan pengabdian melalui Program Iptek bagi masyarakat secara rinci adalah merancang model gambar dan peralatan permesinan, merenovasi dan membuat perahu kayu jenis sopek dan sejenisnya, melakukan pelatihan perbaikan/perawatan perahu kayu jenis sopek dan sejenisnya meliputi renovasi bodi, pelapisan lambung, mesin penggerak dan alat tangkap dan memberikan konsultasi secara rutin perbaikan/perawatan perahu kayu dan sejenisnya.

\section{METODE PELAKSANAAN}

Solusi permasalahan di nelayan tradisional yang sangat komplek (kemiskinan, lingkungan kumuh, sanitasi, kesehatan, pendidikan kriminalitas dan sektor pendukung nelayan) perlu penanganan dan penyelesaian secara terintegrasi meliputi mendengarkan aspirasi langsung dari nelayan, pelaksanaan secara bertahap/berkelanjutan dan melibatkan instansi-instansi terkait. Dan mendasarkan pada skala prioritas, tim pengabdian bersama dengan mitra kelompok nelayan Rejeki Bahari menyetujui kegiatan pengabdian ke depan difokuskan pada perawatan, perbaikan dan teknik pembuatan perahu sopek atau kapal kecil teristimewa pada mesin penggerak dan lambung perahu (Rois, 2016, Subhari, 2016). Dan untuk mencapai perawatan, perbaikan dan teknik pembuatan perahu sopek atau kapal kecil secara maksimal, tim pengabdian menyusun kegiatan yang secara detail terdiri dari pemahaman dan pendalaman perahu atau kapal kayu, teknik dan peralatan renovasi dan pembuatan perahu, pemahaman dan pendalaman kerusakan kapal, rancang bangun perahu kayu jenis sopek dan sejenisnya dan pelaksanaan di kelompok nelayan.

\section{Perancang Perahu Sopek}

Sesuai kesepakatan dengan mitra, kegiatan difokuskan proses pendampingan, pembelajaran, perancangan dan pembuatan perahu sopek. Obyek perahu sopek ratarata telah dimiliki oleh nelayan di pantai Semarang dan telah banyak dipakai sebagai perahu penangkap ikan. Identifikasi di lapangan bersama mitra nelayan menunjukkan bahwa perahu nelayan rata-rata berukuran kecil dan terbuat dari kayu. Perahu nelayan biasa dinamakan perahu sopek. Dan data perahu sopek rata-rata mempunyai dimensi ukuran:

$\begin{array}{ll}\text { Panjang (LOA) } & : 7-8 \text { meter, } \\ \text { Lebar (BOA) } & : 2,5-3 \text { meter, } \\ \text { Sarat ( T ) } & : 0,4-0,7 \text { meter dan } \\ \text { Tinggi Geladak( } \mathrm{H}) & : 1,3-1,5 \text { meter (perahu yang ada geladaknya) } \\ \text { Koefisien Balok ( Cb ) } & : 0,5-0,7 \\ \text { Mesin } & : \text { Kubota/Yanmar/Dong Feng } \\ \text { Tenaga Mesin } & : 12-16 \text { PK } \\ \text { Posisi mesin } & : \text { Tempel/out board }\end{array}$




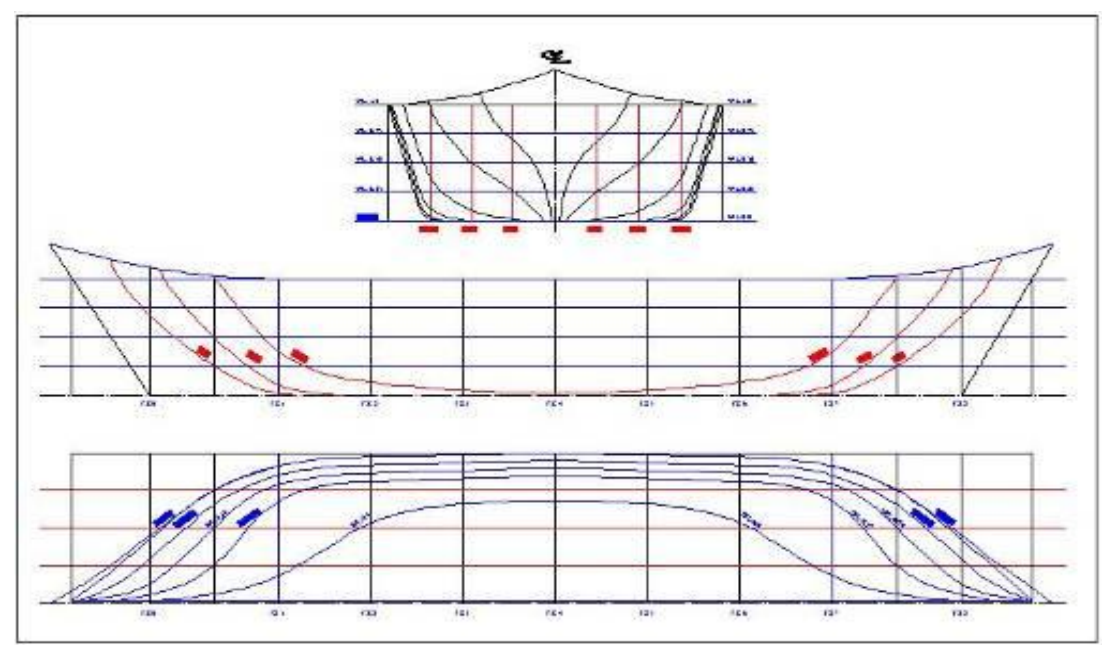

Gambar 1. Gambar perahu sopek (sumber: Said, 2010)

Selanjutnya proses pembuatan dan perbaikan seharusnya juga mendalami desain perahu sopek. Desain perahu sopek pada prinsipnya terdiri gambar rencana garis (lines plan) dan gambar rencana umum (general arrangement). Rencana garis adalah gambar proyeksi perahu ditinjau dari beberapa padangan/potongan meliputi pandangan potongan melintang perahu (body plan), pandangan potongan memanjang perahu (sheer plan) dan pandangan potongan bidang garis air perahu (water lines plan) seperti ditunjukkan di gambar 1. Gambar rencana umum difokuskan proses desain dengan membuat tata letak ruang-ruang (layout), tanki-tanki, ruang di atas geladak, dudukan mesin dan pendukung. Hasil desain gambar rencana umum dapat menentukan kedudukan titik berat perahu berdasarkan penempatan beban di dalam perahu. 

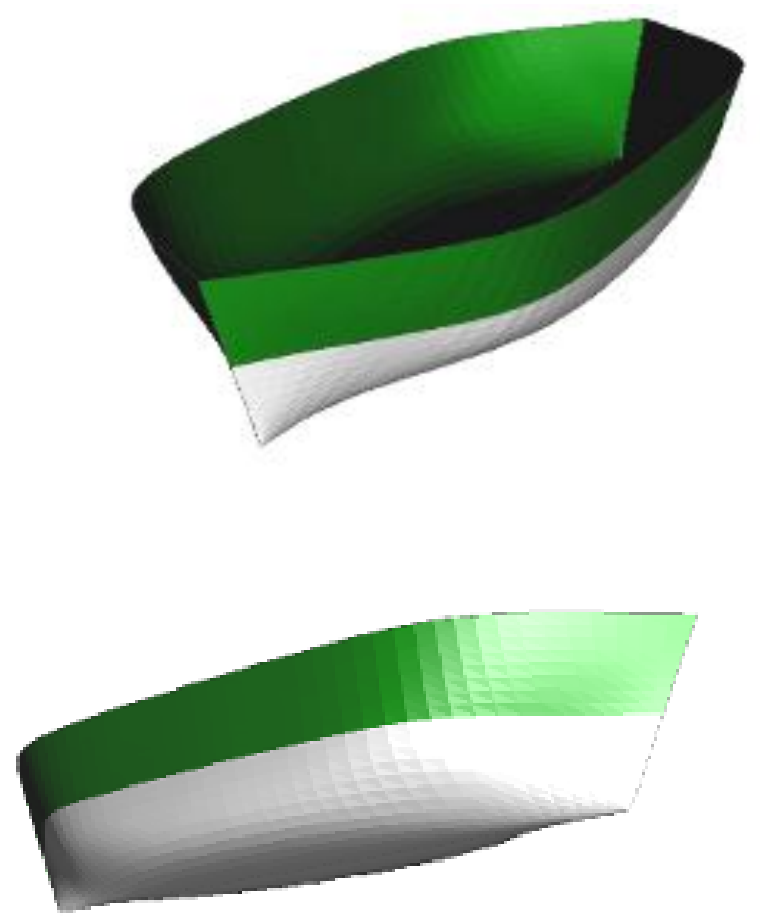

Gambar 2. Lambung perahu sopeki (sumber: Said: 2010)

\section{Peralatan untuk Pembuatan Perahu Kayu}

Alat merupakan barang yang dipakai untuk mengerjakan sesuatu, perkakas, perabotan seperti tukang kayu. Pertukangan adalah pekerjaan-pekerjaan tukang (tukang kayu). Dapat disimpulkan bahwa alat pertukangan adalah suatu barang yang dipakai oleh tukang untuk mempermudah mengerjakan perabotan yang dikuasainya. Tukang adalah pekerja tangan dengan kepandain istimewa. Alat pertukangan bisa dikatakan nyawa dari para tukang, walaupun tukang memiliki kepandaian istimewa, tanpa alat pertukangan para tukang tidak akan bisa mengerjakan pekerjaannya. Tukang dan alat pertukangan saling melengkapi. 


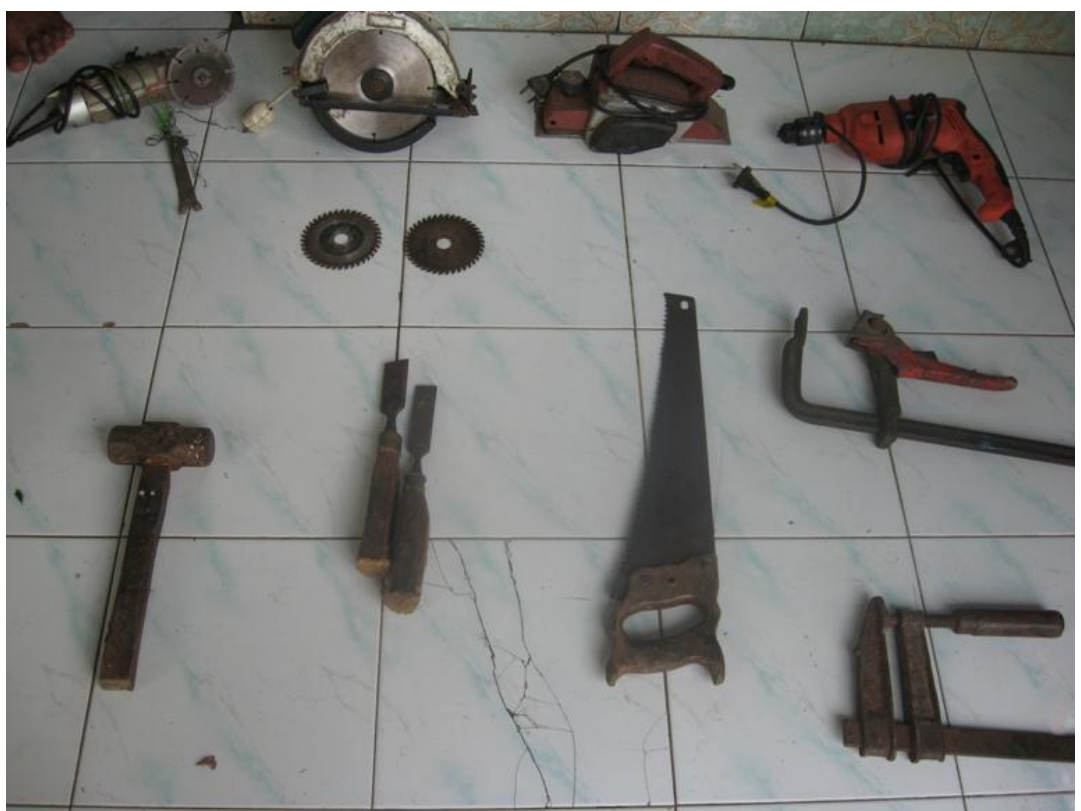

Gambar 3. Peralatan pertukangan untuk renovasi dan pembuatan perahu kayu.

Alat pertukangan umumnya familiar dengan suatu barang yang dipakai oleh tukang mebel (kayu) untuk mempermudah mengerjakan perabotan mebel (kayu) sehingga menjadi barang yang dimaksud misalnya: lemari, pintu, kusen, meja, kursi, dsb. Di bidang konstruksi kapal atau perahu terutama kapal atau perahu kayu, alat pertukangan sangat penting untuk membentuk kayu, sehingga kayu yang pertamanya polos sehingga menjadi kayu yang terbentuk. Para tukang galangan kapal kayu akan sangat terbantu oleh alat pertukangan. Beberapa peralaan pertukangan untuk renovasi dan pembuatan perahu kayu ditunjukkan di gambar 3.

\section{HASIL DAN PEMBAHASAN}

Identifikasi di lapangan bersama mitra nelayan menunjukkan bahwa perahu nelayan rata-rata berukuran kecil dan terbuat dari kayu. Perahu nelayan biasa dinamakan perahu sopek. Untuk perbaikan lambung perahu, identifikasi lapangan pada beberapa perahu menunjukkan tipe-tipe kerusakan lambung perahu yang berbeda. Beberapa kerusakan lambung perahu tersebut meliputi adanya tumbuhan, hewan dan benda lain yang menempel di lambung, cat pelapis mengelupas, bagian sambungan antar kayu di lambung mulai renggang dan kelihatan berlubang, pelapukan kayu dan lambung berlubang sehubungan adanya benturan atau bagian kayu lambung lepas. Adanya kerusakan atau lubang-lubang kecil berdampak pada bocornya lambung dan efek lebih jauh air akan masuk ke perahu. Nelayan dalam waktu tertentu harus menguras dan membuang air yang masuk di dalam perahu. Kondisi ini tentu akan membahayakan nelayan saat melaut terlebih pada saat gelombang tinggi. 
60 J-Abdipamas, Vol 2, No.1 April, 2018
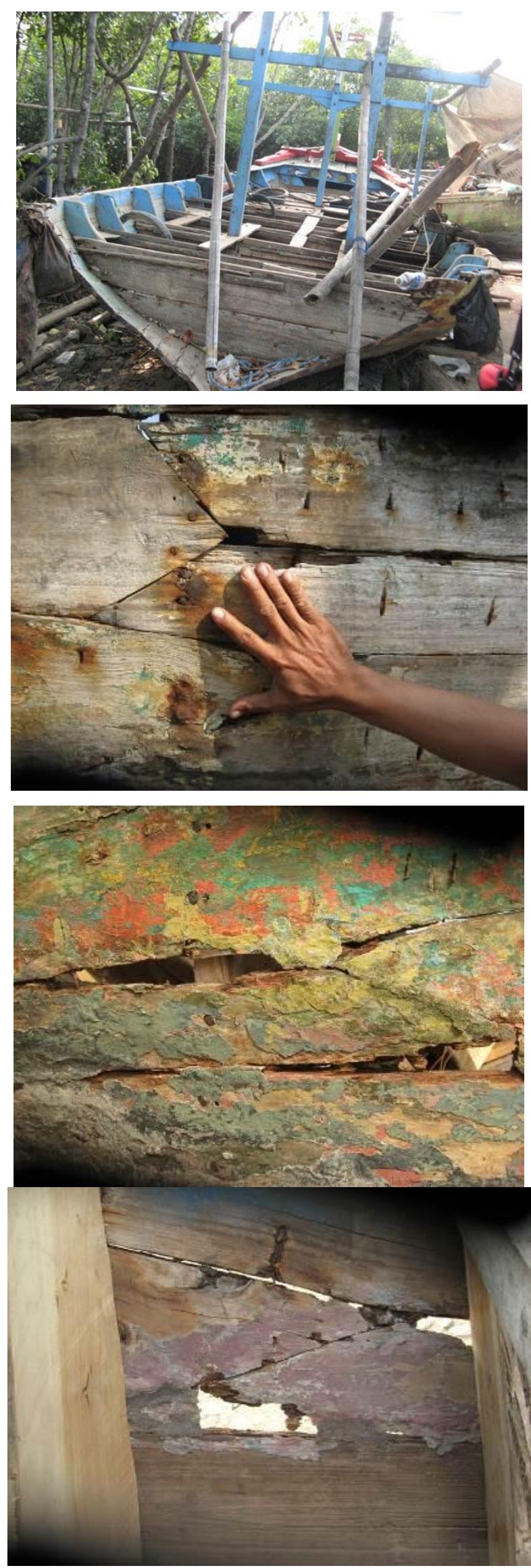

Gambar 4. bentuk kerusakan di lambung perahu 


\section{Identifikasi Peralatan untuk Perbaikan Lambung Perahu}

Di bidang konstruksi kapal atau perahu terutama kapal atau perahu kayu, alat pertukangan sangat penting untuk membentuk kayu, sehingga kayu yang pertamanya polos sehingga menjadi kayu yang terbentuk. Para tukang galangan kapal kayu akan sangat terbantu oleh alat pertukangan. Beberapa peralaan pertukangan untuk renovasi dan pembuatan perahu kayu ditunjukkan di gambar 5. Di bidang konstruksi kapal atau perahu terutama kapal atau perahu kayu, alat pertukangan sangat penting untuk membentuk kayu, sehingga kayu yang pertamanya polos sehingga menjadi kayu yang terbentuk. Para tukang galangan kapal kayu akan sangat terbantu oleh alat pertukangan. Beberapa peralaan pertukangan untuk renovasi dan pembuatan perahu kayu meliputi gergaji kayu (mesin dan manual), bor, pasah, gerinda, tatah (berbagai ukuran), clem/pencepit dan peralatan pendukung lain.
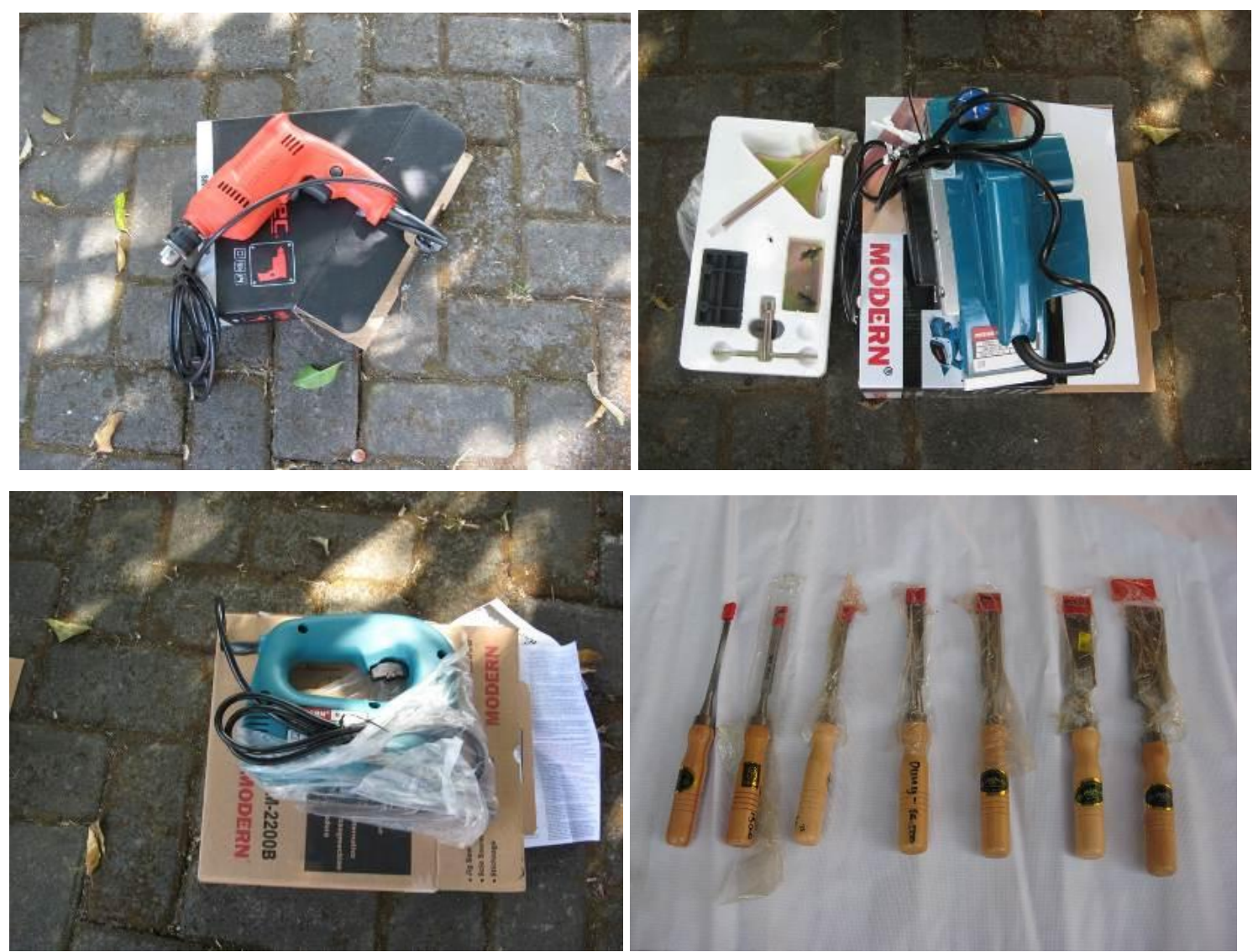

Gambar 5. Beberapa peralatan pertukangan bermesin

\section{Tahapan Perbaikan Lambung Perahu}

Proses perawatan dan perbaikan kapal pada bagian badan (lambung) kapal di mitra nelayan pada prinsipnya dilakukan melalui beberapa tahapan meliputi pencucian seluruh bagian kapal, pemakalan, pendempulan dan pengecatan kapal. Proses pencucian dilakukan dengan air tawar dan dilanjutkan dengan proses pengeringan dan seluruh proses di atas dilakukan di darat. Selanjutnya proses 
pemakalan dimulai dengan pelepasan (pengelotokkan) cat yang telah lama dan telah terkelupas, dilanjutkan dengan proses penggantian papan-papan lambung yang telah lapuk karena usia pemakaian. Tahapan pemakalan di mitra nelayan ditunjukkan di gambar 6. Kemudian proses pakal adalah kegiatan menambal bagian-bagian antar papan pada lambung kapal dengan menggunakan makjun. Makjun merupakan semacam serat terbuat dari rami. Serat ini dimasukkan pada sela-sela papan dengan menggunakan palu dan pakal.

\section{Pelapisan Lambung dengan Resin Kedap Air}

Proses perawatan kapal yang rutin dilakukan setiap tahun adalah pengecatan lambung perahu. Pengecatan lambung perahu dilakukan tidak hanya pada perahu yang menjalani perawatan besar tetapi juga perahu-perahu yang secara fisik tidak rusak. Kerusakan di lapisan pelindung lambung kapal (yang merupakan lapisan cat) perlu dibersihkan dan dilapisi ulang setiap tahun. Dan proses pengecatan dimulai dengan pemberian cat menje pada seluruh bagian lambung kapal. Pemberian cat menje bermula dari lunas (dasar) sampai batas water line tertinggi. Cat ini diharapkan dapat menjadi anti fouling dan anti karat bagi lambung kapal. Proses pengecatan kapal dilakukan oleh kelompok pekerja dengan jumlah 5-6 orang sehingga proses pengecatan dapat diselesaikan selama 1-2 hari.

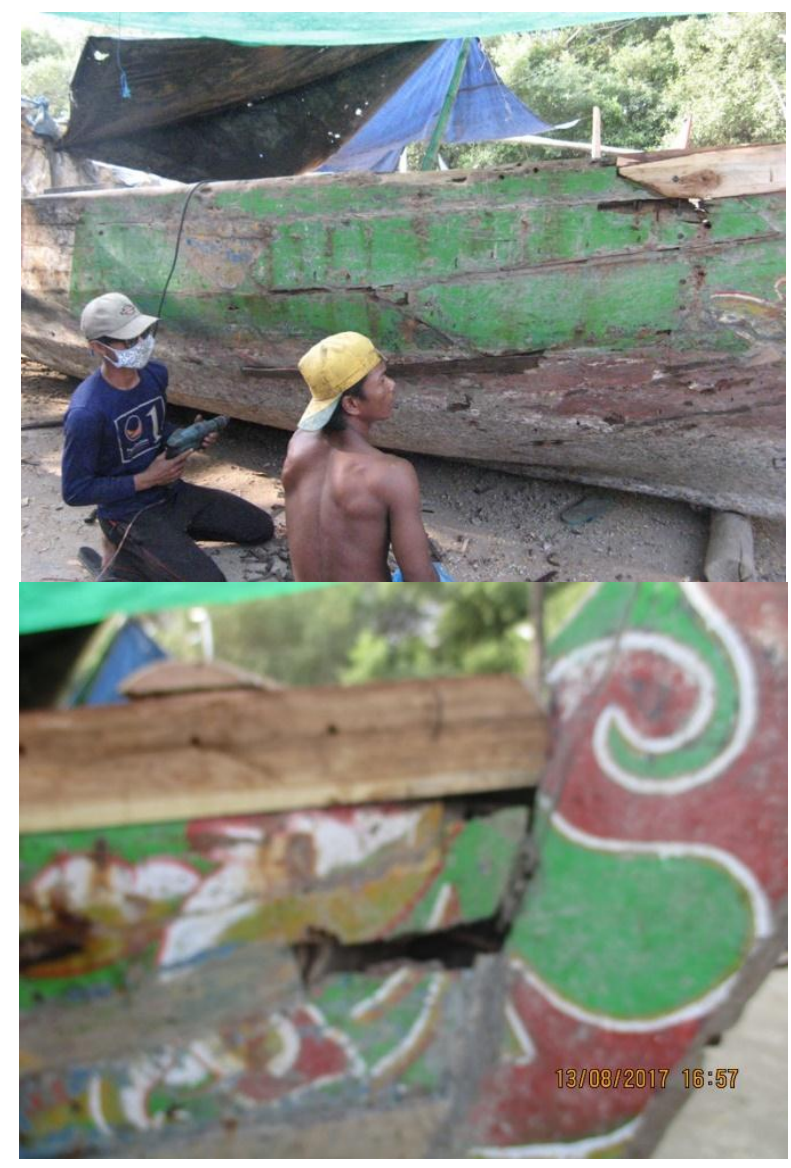




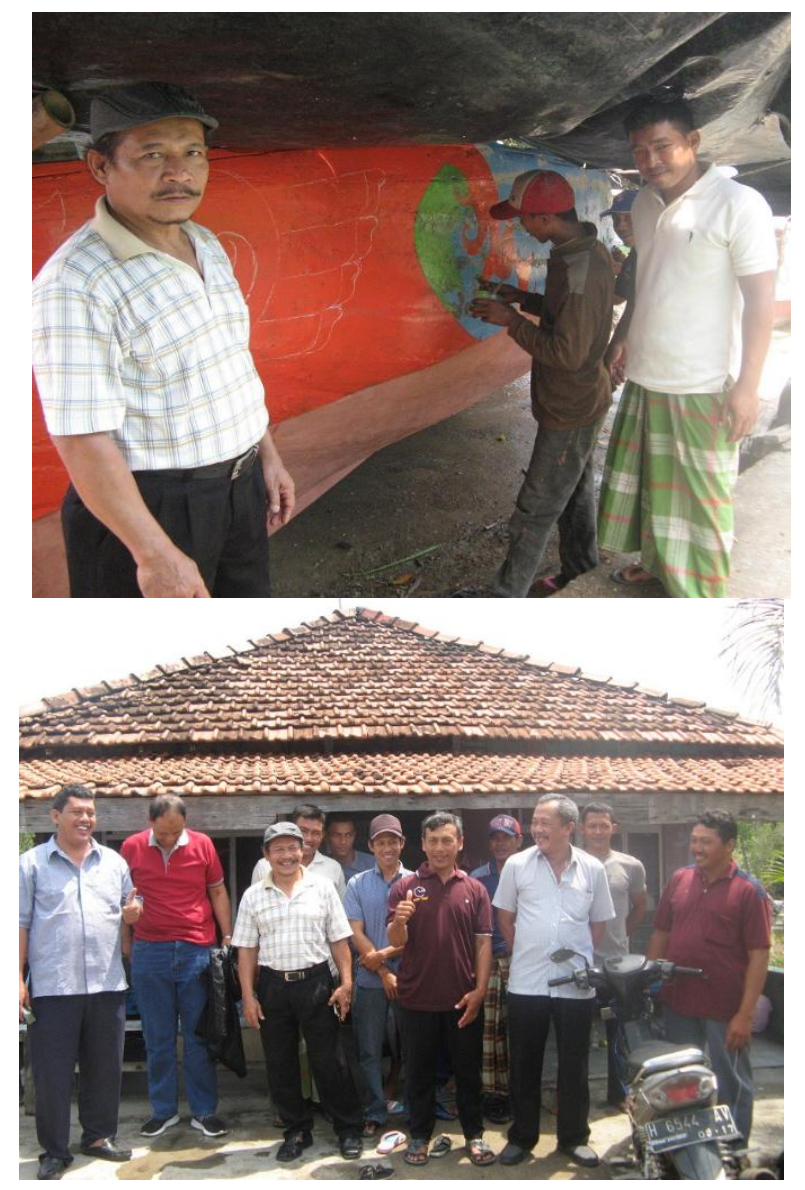

Gambar 6. Dokumentasi kegiatan perbaikan lambung perahu

\section{SIMPULAN}

Proses perawatan dan perbaikan kapal pada bagian badan (lambung) kapal di mitra nelayan pada prinsipnya dilakukan melalui beberapa tahapan meliputi pembersihan dan pencucian seluruh bagian kapal, penambalan (pemakalan), pendempulan dan pengecatan. Proses pengecatan melalui beberapa tahapan yakni pembersihan permukaan, penambalan kalau ada yang mulai retak dan berlubang, pengeringan, penghalusan, pelapisan dasar dan pengecatan. Beberapa peralatan perawatan dan perbaikan lambung perahu bahkan peralatan untuk renovasi dan pembuatan perahu kayu meliputi gergaji kayu, bor, pasah, gerinda, tatah (berbagai ukuran), clem/pencepit dan peralatan pendukung lain. Perawatan lambung perahu mendasarkan pada tingkat kerusakan dinding lambung perahu. Perawatan dengan penambalan tergolong perawatan besar dan diawali dengan pelepasan pelapis dan penggantian papan-papan lambung yang telah lapuk. Pengecatan lambung perahu dilakukan tidak hanya pada perahu yang menjalani perawatan besar tetapi juga perahu-perahu yang secara fisik tidak rusak.

\section{UCAPAN TERIMA KASIH}

Kami dari hati yang paling dalam mengucapkan terima kasih kepada semua pihak yang telah terlibat dalam pengabdian ini terutama mahasiswa, teknisi dan PSD 
III Teknik Sipil, Perkapalan dan Mesin, Sekolah Vokasi Undip. Terima kasih kepada DRPM melalui Skim Iptek bagi Masyrakat yang telah mendanai kegiatan pengabdian melalui Direktorat Riset dan Pengabdian kepada Masyarakat Direktorat Jenderal Penguatan Riset dan Pengembangan Kementerian Riset Teknologi dan Pendidikan Tinggi Sesuai dengan Surat Perjanjian Penugasan Program Pengabdian kepada Masyarakat Nomor: 007/SP2H/PPM/DRPM/V/2017, tanggal 5 Mei 2017

\section{DAFTAR RUJUKAN}

Muhammad. (2002). "Penentuan Status Sumberdaya Perikanan Jawa Timur”, Fakultas Perikanan, Unibraw, Malang

Rois, A.,. (2014). "Wawancara: Ketua Kelompok Nelayan Rejeki Bahari", Survey Langsung di Kelompok Nelayan Rejeki Bahari.

Said, S.D. (2010)."Analisa Efisiensi Penggunaan Daya Mesin Kapal Purse Seine di Perairan Pekalongan", Laporan Tesis di Undip Semarang.

Subhari. (2016).'Wawancara: Anggota Nelayan Rejeki Bahari", Survey Langsung di Kelompok Nelayan Doa Barokah.

Yahya, M.A. (2001)."Perikanan Tangkap Indonesia: Suatu Pendekatan Filosofis dan Analisis Kebijakan", Makalah Falsafah Sains (PP 702), Program Pascasarjana/S3 Institut Pertanian Bogor, Email : yahya_aliid@yahoo.com 